\title{
Myślenie krytyczne: kilka uwag historycznych i teoretycznych
}

\author{
Andrzej DĄBROWSKI*
}

\begin{abstract}
Critical thinking: some historical and theoretical remarks: In the paper, I defend a version of critical thinking. Firstly, I reconstruct the historical context surrounding the emergence of the critical thinking movement. There are various important intuitions and concepts of critical thinking — ones authored by John Dewey, Robert H. Ennis, Richard W. Paul, among many others - that have played an important role in understanding this type of thinking. Many definitions of critical thinking constitute concise and overly narrow formulas and fail to help us understand the subject, consequently I propose my own definition. By critical thinking I mean analytical, evaluative and argumentative cognitive functions. Next I discuss the basic dialogical context in which critical thinking develops and analyse the most important elements of critical thinking such as: analysis, evaluation and argumentation. I see critical thinking to be an important and valuable form of thinking. However, I do not argue in favour of critical thinking as the primary educational ideal. Rather, it plays an instrumental and supportive role in thinking, acting and life.
\end{abstract}

\section{KEYWORDS}

critical thinking; analysis; reasoning; argumentation; John Dewey; Robert H. Ennis; Richard W. Paul; Lvov-Warsaw School

* Dr hab., Instytut Filozofii i Socjologii, Katedra Epistemologii, Logiki i Kognitywistyki, Uniwersytet Pedagogiczny im. KEN w Krakowie. E-mail: andrzej.dabrowski@up.krakow.pl. 


\section{WPROWADZENIE}

W artykule zaprezentuję koncepcję, a właściwie pewien wariant myślenia krytycznego (MK). Wyjdę od uwag natury historycznej. Ograniczę się przede wszystkim do kilku nazwisk i faktów związanych z historią edukacji północnoamerykańskiej, bo projekt MK początkowo dotyczył przede wszystkim tego obszaru. Następnie postaram się wyznaczyć podstawowy kontekst MK i jego granice oraz uchwycić najważniejsze jego elementy. Przez MK będę rozumiał myślenie analityczno-ewaluacyjne i argumentacyjne, które może być stymulowane i kształtowane wielorako na wszystkich poziomach edukacji. W niniejszej publikacji ograniczę się do narzędzi, które moim zdaniem powinny bezwzględnie obowiązywać w ramach kursów z krytycznego myślenia na poziomie akademickim ${ }^{1}$. Istnieją różne modele i ambitne programy służące usprawnieniu tej formy myślenia (uwzględniające wiele ważnych elementów logiki formalnej, metodologii i epistemologii, ale także liczne zagadnienia z zakresu psychologii poznawczej). W artykule będę bronić odchudzonej wersji MK. Literatura na temat MK jest olbrzymia i z roku na rok lawinowo jej przybywa, zatem co warto podkreślić - moje rozważania nie mają charakteru kompleksowego, wyczerpującego i konkluzywnego, a jedynie polemiczny — stanowią głos w dyskusji. Mam nadzieję, że zainspiruje on tych, którzy w przyszłości zajmą się projektowaniem kursów MK w Polsce.

\section{POWSTANIE I ROZWÓJ MYŚLENIA KRYTYCZNEGO}

Początków idei MK należy szukać już w filozoficznej działalności Sokratesa (Paul, 1993; Paul \& Elder, 2007; Chaffee, 2010; Giuseffi, 2015; Long, 2015)². Ten grecki myśliciel nie zadowalał się opiniami czy domniemaniami, ale poszukiwał prawdziwych przekonań i rzetelnej wiedzy. W tym celu był otwarty na tych, którzy uważali, że takowe posiadają, prowadził z nimi dialog i uważnie słuchał tego, co mieli mu do powiedzenia. Potrafił żywo i wnikliwie myśleć i takiej samej aktywności umysłowej oczekiwał od swoich rozmówców. Rezultaty tych rozmów były różne. Kolejne pytania, jakie stawiał Sokrates swoim interlokutorom, ujawniały różnego rodzaju błędy i aporie, uświadamiały pozorność

${ }^{1}$ Oczywiście kurs taki wymagałby bardziej szczegółowego opracowania, co nie jest moim celem. Tutaj wskazuję jedynie na pewien kierunek i sygnalizuję niektóre problemy oraz zagadnienia, jakie mogą się w nim znaleźć. Wiedza i umiejętności, o których piszę, przydatne są wszystkim, choć nie wszyscy w tym samym stopniu będą ich potrzebowali — przywoływane zagadnienia stanowią bowiem integralną część programu nauczania filozofii na poziomie akademickim, a zatem studentom filozofii powinny one być dobrze znane.

${ }^{2}$ Przykładowo John Chaffee w swoim popularnym podręczniku stwierdza: „Grecki filozof Sokrates był pod wieloma względami oryginalnym myślicielem krytycznym” (Chaffee, 2010: 52). Przekład cytatów z prac obcojęzycznych, jeśli nie zaznaczono inaczej — A.D. 
ich wiedzy (metoda elenktyczna). Czasami poprzez kontynuowanie dialogu (który był często przez zawstydzonych rozmówców przerywany) oraz ponowne definiowanie problemu udawało się Sokratesowi wydobyć od nich prawdziwe przekonania (metoda majeutyczna). W praktyce zatem postawa ateńskiego filozofa zdradza wiele elementów charakterystycznych dla współczesnej idei MK: otwartość, żywe i dociekliwe myślenie, definiowanie i stosowanie zasad logiki, rzeczywiste poznanie i wznoszenie się na wyższy poziom samoświadomości. Wielu późniejszych myślicieli podejmowało refleksję nad myśleniem i dążyło do podniesienia jego standardów (na przykład Francis Bacon i René Descartes)³. Jednak za twórcę idei współczesnego MK uważa się amerykańskiego pragmatystę Johna Deweya (1859-1952) (Blair, 2006; Hitchcock, 2017).

Filozof ten w pracy Jak myślimy? (How we think; 1910) podjąt próbę ustalenia, czym jest właściwy sens słów „myśleć” i „myśl”. W tym celu zaproponował zbadanie kilku typowych sytuacji, w których używa się tych terminów. Po pierwsze, zauważa Dewey, „myślenie” może znaczyć wszystko, co przeżywamy, co przychodzi nam do głowy (zdziwienie pod wpływem bodźca, wspomnienie, wyobrażanie lub fantazjowanie). Po drugie, myślimy dzięki temu, co jest czysto umysłowe, abstrakcyjne, oderwane od bezpośredniego doświadczenia (czego nie widzimy, nie słyszymy, nie czujemy). Po trzecie, myślenie może być zawężone do mniemania opartego na świadectwie, nauczaniu lub autorytecie. Takie myślenie przyjmuje w sposób bezwiedny mniemania i przedsądy, bez próby ustalenia podstaw, na których się opierają. Po czwarte, myślenie może mieć charakter działania na przekonaniach, które pozostają w relacji do innych przekonań, są uzasadniane przez jedne i stanowią racje dla innych. Takie myślenie, które szuka podstaw swoich przekonań i sprawdza, na ile wystarczają one do ich uzasadnienia, oraz bierze pod uwagę logiczne konsekwencje tychże przekonań, jest uznawane przez Deweya za myślenie par excellence i nazwane zostaje przez niego myśleniem refleksyjnym:

Myślenie refleksyjne jest czynnym, wytrwałym i uważnym rozważaniem jakiegoś mniemania lub przypuszczalnej formy wiedzy - w świetle podstaw, na których się wspiera, oraz wniosków, do których doprowadza.

${ }^{3}$ Francis Bacon opisał kilka ważnych błędów (idoli), jakim podlega umyst: 1) idole plemienne (idola tribus), bezkrytyczne przyjmowanie tego, co zmysły nam podpowiadają; 2) złudzenia jaskini (idola specus), interpretowanie świata z własnej, subiektywnej perspektywy; 3) idole rynku (idola fori), błędy wynikające z nieprawidłowego użycia języka; 4) idole teatru (idola theatri), bezkrytyczna wiara w autorytety intelektualne, w stare idee i hipostazy (Bacon, 1955). Natomiast René Descartes w Rozprawie o metodzie zaproponował strategię poznawczą, w której najważniejsze były cztery reguły: 1) nigdy nie przyjmuj czegokolwiek za prawdę bez posiadania oczywistych powodów; 2) badany problem podziel na tak wiele elementów, jak to jest możliwe; 3) zawsze zaczynaj od spraw łatwiejszych do poznania i przechodź do coraz trudniejszych;

4) dokładnie ustal wyczerpujący katalog problemów do rozwiązania — niczego nie pomijaj (Descartes, 2002). 
Każdy z trzech pierwszych rodzajów myślenia może wreszcie doprowadzić do tego ostatniego typu, ale jego pojawienie się oznacza świadomy i dowolny wysiłek w celu oparcia mniemania na mocnych podstawach argumentów (Dewey, 1988: 30)4.

Według Deweya z refleksją ściśle wiąże się jakaś sytuacja problemowa. Jego zdaniem nie można myśleć refleksyjnie bez zwrócenia uwagi na jakąś trudność, problem, który niepokoi i - w pewnym sensie - wyprowadza podmiot z równowagi. Trudność tę należy najpierw jednak zidentyfikować, poprawnie nazwać i w końcu znaleźć dla niej odpowiednie rozwiązanie. Czasami będzie to trudność praktyczna, życiowa, moralna lub społeczno-polityczna, innym razem czysto teoretyczna. Dewey wyodrębnił pięć logicznie różnych stopni myślenia, które ostatecznie prowadzą do rozwiązania problemu: 1) odczucie pewnego typu trudności (sprzeczności lub wątpliwości), 2) określenie istoty problemu, 3) szukanie rozwiązań - formułowanie pomysłów, hipotez i prototeorii, 4) wyprowadzenie drogą rozumowania wniosków z przypuszczalnego rozwiązania, 5) dalsze obserwacje prowadzące do przyjęcia lub odrzucenia hipotezy - empiryczna weryfikacja hipotezy (Dewey, 1988: 102).

Innym filozofem, który poważnie wpłynął na rozwój MK w USA, był Israel Scheffler (1923-2014) (Scheffler, 1960; Scheffler, 1966; Scheffler, 1973; Scheffler, 1985; Scheffler, 1997). W swoich pracach krytykowat on podejście encyklopedyczne w edukacji, które polegało na gromadzeniu i przekazywaniu wiedzy. Jego zdaniem istotą nauczania powinno być spotkanie nauczyciela z uczniem i racjonalna wymiana myśli między nimi. Postulował, by szkoły podążały za tradycją sokratejską i zachęcały uczniów do refleksji, szukania racji i krytycyzmu. Nie zgadzał się z Deweyem w kwestii tego, że myślenie refleksyjne sprowadza się do rozwiązywania problemów. Jego zdaniem nie można zgubić z pola widzenia idei myślenia dla samego myślenia. Nadrzędnym celem edukacji powinno być - według niego — kształtowanie wolnego i krytycznego umysłu. Krytycyzm ten zaś ma przejawiać się nade wszystko w poszukiwaniu dobrych racji i dążeniu do uzasadnienia swoich przekonań.

Wspieranie rozwoju krytycznego umysłu i racjonalnego myślenia, którego skutkiem ma być umiejętność samodzielnego sądzenia, było postrzegane przez Schefflera jako jeden z najważniejszych celów kształcenia. Środkiem do osiągnięta tego celu, do formowania

${ }^{4} \mathrm{~W}$ tradycji filozoficznej terminy „refleksja” i „myślenie refleksyjne” miały różne znaczenia, od szerokiego, które obejmowało wszelkie formy rozważania i zastanawiania się, po stosunkowo wąskie, „Zwrot w stronę wnętrza”, „śledzenie własnych myśli” (łac. reflexio — 'odbicie', 'zwrot do tyłu'). Obok aktu spostrzeżenia (lub innego przeżycia) pewien podmiot może ująć to, co spostrzegł, za pomocą innego odrębnego aktu o charakterze refleksyjnym. $\mathrm{Na}$ określenie tego drugiego aktu, charakteryzującego się pewną retrospektywnością, scholastycy używali wyrażenia reflexio in actu signato. W późnym średniowieczu stosowano też formułę reflexio in actu exercito, która podkreślała równoczesność aktu spostrzegania i świadomości tego, że akt ten aktualnie się dokonuje. Na ten temat zob. Chudy, 1984. 
umysłu krytycznego, pytającego, odpowiedzialnego i wolnego jest nauczanie myślenia krytycznego (Wasilewska-Kamińska, 2016: 31).

W przeglądzie najważniejszych stanowisk dotyczących MK nie sposób pominąć Roberta H. Ennisa (ur. 1928) czy Richarda W. Paula (1937-2015)5. Ten pierwszy już w czasie studiów doktoranckich pracował nad tym zagadnieniem - jego doktorat (The development of a critical thinking test) dotyczyt kwestii testowania tego sposobu myślenia ${ }^{6}$. Przez około pół wieku Ennis pracował nad różnymi aspektami $\mathrm{MK}$, a w latach 60 . XX wieku próbował wyraźnie określić jego cel. Doszedł do wniosku, że powinna nim być „poprawna ocena twierdzeń” (the correct assessing of statements) (Ennis, 1962: 83). Ten nadrzędny cel jego zdaniem można uzyskać, jeśli spełni się kilkanaście warunków: 1) uchwycenie znaczenia wypowiedzi (twierdzenia): czy na pewno znaczy ona to a to; 2) ocena, czy wypowiedź została wystarczająco jasno wyartykułowana; 3) ocena, czy twierdzenia są spójne; 4) ocena, czy konkluzja jest koniecznie logiczna; 5) ocena, czy twierdzenie jest dostatecznie precyzyjne; 6) ocena, czy twierdzenie oparte jest na zasadzie: czy jest zgodne z regułą; 7) ocena, czy twierdzenie oparte jest na obserwacji i jest wiarygodne; 8) osądzenie, czy wyprowadzony wniosek jest dobrze uzasadniony; 9) osądzenie, czy problem został trafnie rozpoznany; 10) osądzenie, czy problem został dobrze zdefiniowany; 11) osądzenie, czy w wypowiedzi nie ma ukrytych założeń, przesądów; 12) osądzenie, czy twierdzenie jest prawdziwe (Ennis, 1962: 84).

${ }^{5}$ Do tych, którzy wpłynęli na rozwój ruchu na rzecz MK, należy też Benjamin S. Bloom, który opracował klasyfikację celów nauczania: pozyskiwanie wiedzy — rozumienie — zastosowanie analiza - synteza - ocena (Bloom, 1956). Na powstanie i rozwój ruchu na rzecz MK miały też wpływ różne instytucje i projekty badawcze w USA. Już w latach 30. XX wieku Stowarzyszenie Edukacji Progresywnej (Progressive Education Association, 1919-1955), którego działalność obejmowała między innymi unowocześnienie i udemokratycznienie edukacji, promowało ideę MK, nawiązując wprost do filozofii myślenia i edukacji Deweya. Jeszcze większe znaczenie miał eksperyment Edwarda M. Glasera, którego celem było między innymi zbadanie skuteczności MK i opracowanie bardziej efektywnych metod i narzędzi do jego uczenia. Glaser inspirował się ideą myślenia Deweya oraz badaniami Goodwina Watsona (Glaser, 1941). W ten sposób powstał test psychometryczny Watson-Glaser Critical Thinking Appraisal, który - po wielu zmianach i ulepszeniach - stosowany jest wciąż do badania: 1) poprawności wnioskowań, 2) rozpoznawania założeń, 3) oceny argumentów, 4) rozumowania dedukcyjnego i 5) logicznej interpretacji. Więcej na ten temat zob. Wasilewska-Kamińska, 2016: 18-58.

${ }^{6}$ Ennis rozpoczął studia inżynierskie na MIT w 1945 roku, ale po czterech semestrach przerwał je, by podjąć służbę $\mathrm{w}$ armii amerykańskiej. Doświadczenie Hiroshimy pokazało mu, jak ważna jest mądrość, której zwyczajnie ludzkości brakuje. Bezskutecznie zabiegał o nią na studiach filozoficznych w University of Wisconsin (Madison). Historia filozofii, idee pozytywizmu logicznego, ale także filozofia Deweya (taka, jaką mu prezentowano) nie pomogły w znalezieniu tego, czego szukał. Zwrócił się w stronę filozofii edukacji, ale najpierw jako praktyk nauczyciel w szkole. Idee progresywnej edukacji utwierdziły Ennisa o ważnej roli MK dla życia osobistego, zawodowego i obywatelskiego. Od tamtego czasu niestrudzenie pracuje on na rzecz MK. 
Później, od połowy lat 80. XX wieku, Ennis promował nieco zmodyfikowaną definicję MK: „myślenie krytyczne to rozumne, refleksyjne myślenie skoncentrowane na podjęciu decyzji: w co wierzyć lub co zrobić" (Critical thinking is reasonable, reflective thinking that is focused on deciding what to believe or do) (Ennis, 1987: 10; por. Ennis, 1991; Ennis, 1996). MK to myślenie kierowane rozumem, które służy życiu teoretycznemu i/lub praktycznemu, tj. służy szukaniu dobrych uzasadnień i argumentów dla myślenia i działania. W MK wpisane są zatem: refleksja, analiza, definiowanie, ocena, argumentacja, podejmowanie decyzji czy rozwiązywanie problemów. Ennis opracował też rozbudowaną taksonomię umiejętności i dyspozycji MK (o uniwersalnym charakterze) (Ennis, 1987).

Własną koncepcję MK zaproponował Paul, jeden z najbardziej rozpoznawalnych działaczy ruchu na rzecz tego zagadnienia, nauczyciel i szkoleniowiec, autor licznych przewodników, podręczników i programów do nauczania $\mathrm{MK}$, twórca fundacji i centrów badawczych. Charakterystyczną cechą jego koncepcji jest nacisk na samoświadomość myślącego podmiotu. W punkcie wyjścia Paul wyróżnia dwa poziomy myślenia: pierwszy - myślenie potoczne, spontaniczne i bezrefleksyjne, pełne uproszczeń i błędów, oraz drugi, na którym porządkujemy własne myśli, dokonujemy ich analizy i oceny - myślenie pogłębione, rzetelne i racjonalne. Jest ono formą metamyślenia: to myślenie skierowane na siebie, samodyscyplinujące, samomonitorujące i samokorygujące, choć zwykle otwarte na innych i na uczciwą komunikację ${ }^{7}$. Ten wyższy poziom to MK. Obejmuje ono wiele różnych umiejętności intelektualnych, ale — zdaniem Paula - nie może się do nich ograniczać. Lepszym wariantem MK jest taki, który implikuje otwartość na inne punkty widzenia, zawiera w sobie intelektualną uczciwość i wrażliwość moralną. Pierwszy wariant — ograniczający się do sprawnego stosowania umiejętności intelektualnych - Paul nazywa słabym MK, a drugi silnym MK (weak versus strong critical thinking) (Paul \& Elder, 2002: 17).

W ogólności nauczanie MK wedle Paula składać się może z dwóch etapów. Pierwszy obejmowałby proces samozrozumienia — zwłaszcza poznanie elementarnych składowych naszego myślenia (pojęć, problemów, założeń, danych, informacji itd.) oraz zrozumienie natury działania naszego umysłu i jego ograniczeń. Jeśli chodzi o ograniczenia i bariery, Paul skoncentrował się zwłaszcza na psychologicznych pułapkach związanych z egocentryzmem czy socjocentryzmem. Drugi etap to poznanie i ćwiczenie standardów MK, które pozwalają przezwyciężyć wszelkie mechanizmy upraszczające i błędy w myśleniu. Standardy te to: jasność, trafność, precyzja, istotność, głębia, perspektywiczność, spójność i poprawność logiczna, doniosłość, sprawiedliwość (myślenie powinno

${ }^{7}$ Jak czytamy w jednym z podręczników do MK: „Myślenie krytyczne to, krótko mówiąc, myślenie nakierowane na siebie, samodyscplinujące, samomonitorujące i samokorygujące. Zakłada ono zgodę na rygorystyczne standardy wysokiej jakości oraz na intelektualne i skrupulatne stosowanie się do nich. Wymaga skutecznej komunikacji i umiejętności rozwiązywania problemów" (Paul \& Elder, 2002: 15). 
być uczciwe - tj. pozbawione uprzedzeń, bezstronne i wolne od błędnych założeń). Koncepcja MK Paula ma też dobrze rozwinięte elementy związane ze sferą życia praktycznego, dotyczące jego planowania i sztuki podejmowania trafnych decyzji ${ }^{8}$.

Później filozof rozwijał i uzupełniał swoją koncepcję o różne nowe aspekty, w wyniku czego straciła ona na wyrazistości. Dobrze widać to na przykładzie próby włączenia w obręb MK myślenia twórczego. Zdaniem Paula przeciwstawienie tych dwóch form myślenia nie ma większego sensu, ponieważ każde MK jest zawsze myśleniem twórczym, a każde myślenie twórcze jest równocześnie MK. Moim zdaniem w niektórych sformułowaniach Paul zbliża się niebezpiecznie do utożsamienia obu typów myślenia (pomijam tutaj te wypowiedzi, w których jest mowa o tym wprost $)^{9}$. Myślenie kreatywne i MK są niewątpliwie ze sobą powiązane. Niektóre elementy mają wspólne (na przykład otwartość, ciekawość). Zwykle jednak w literaturze przedmiotu traktowane są jako dwa różne typy myślenia, którym przyświecają różne cele ${ }^{10}$. Myślenie twórcze jest nastawione na kreowanie nowych, oryginalnych i wartościowych odkryć (w sensie poznawczym, estetycznym, etycznym albo użytkowym). Osoby myślące twórczo nie boją się ryzyka, odważnie rozpatrują wszelkie możliwe - czasami nawet mało prawdopodobne - opcje, szukają nowych rozwiązań i wysoko cenią nowe pomysły. Natomiast rdzeniem MK są analiza, ocena i argumentacja. Osoby myślące krytycznie są bardziej ostrożne, powściągliwe, ale przede wszystkim wedle najlepszych znanych im standardów dążą do oceny tego, co same tworzą, lub tego, co do nich dociera.

Wydaje się, że oba typy myślenia mogą i powinny się uzupełniać. MK w swojej ocenie i uzasadnieniu domaga się twórczości (ewidentnie na

${ }^{8}$ Pewne zasługi dla rozwoju idei MK położył też — wciąż dzisiaj działający — uczeń Schefflera Harvey Siegel. U niego idea ta urosła do rangi ideału. W punkcie wyjścia Siegel przyznaje, że MK musi zawierać różnego rodzaju umiejętności intelektualne, potrzebne do analizy i oceny wypowiedzi i zawartych w nich racji, ale postuluje też, aby więcej uwagi przykładać do ksztattowania ducha krytycznego, który w dużej mierze zależy od takich dyspozycji, jak docenianie i chęć stosowania poprawnych rozumowań i silnych racji (szacunek dla racjonalności). Przede wszystkim jednak Siegel argumentuje, aby MK uznać za fundamentalny ideał edukacyjny. Przemawiać mają za tym następujące argumenty: 1) MK wzmacnia w uczniach i studentach godność i własną autonomię, 2) MK przygotowuje uczniów do dorosłego życia, 3) MK wpisuje się w pielęgnowanie tradycji racjonalności, która jest w centrum działań edukacyjnych poprzez nauczanie przedmiotów ścisłych, przyrodniczych, społecznych i humanistycznych (Siegel, 1988; Siegel, 1989; Siegel, 1993; Siegel, 1997; Siegel, 1999; Siegel, 2003).

9 „Kiedy rozumiemy myśl krytyczną i twórczą prawdziwie i głęboko, uznajemy je za nierozłączne, zintegrowane i jednolite” (Paul \& Elder 2004: 1).

${ }^{10}$ Pogląd ten jest na tyle powszechny, że Arthur S. Reber podaje go w swojej krótkiej słownikowej charakterystyce: „Myślenie krytyczne przeciwstawia się często myśleniu kreatywnemu [...], ponieważ to ostatnie prowadzi do nowych spostrzeżeń i rozwiązań, podczas gdy pierwsze służy jedynie sprawdzeniu, czy istniejące już idee i rozwiązania nie zawierają błędów” (Reber, 2000: 389). 
przykład w przypadku stosowania rozumowania abdukcyjnego), natomiast myślenie twórcze często żąda samoświadomości, analizy i oceny procesu twórczego oraz potencjalnie uzyskanych rezultatów. Gdyby tak nie było, te dwa typy myślenia przybierałyby karykaturalną postać. Krytycyzm MK bez kreatywności będzie zwykłą ewaluacją, wartościowaniem, wyłapywaniem potknięć, krytykanctwem, w pewnym sensie: obstrukcją. Natomiast kreatywność bez krytycyzmu będzie zwykłym nowinkarstwem, efekciarstwem, a czasami jedynie pretensjonalną prowokacją.

W gruncie rzeczy podmiot myślący to coś więcej niż podmiot myślący krytycznie lub podmiot myślący twórczo. To podmiot, który jest świadomy tych (i innych) form myślenia i który potrafi umiejętnie się nimi posługiwać. Czasami w większym stopniu dopuszcza do głosu wyobraźnię i myślenie twórcze, czasami - MK. Innymi słowy, podmiot myślący tworzy, odkrywa i wytwarza nowe przekonania, idee i wytwory, ale też nieustannie analizuje, bada je i poddaje ewaluacji. Stale monitoruje, czy X jest na właściwej ścieżce, w jaki sposób przebiega jego myślenie, czy jest ono dość jasne, poprawne i spójne, jak przebiega jego twórczość, czy dobrze rokuje itp.

Już ta wstępna i pobieżna analiza wskazuje na wielość źródeł i mnogość koncepcji MK. Niektóre z nich akcentują refleksyjność i zdolności metapoznawcze, inne - kompetencje logiczne lub umiejętność uzasadniania, a jeszcze inne koncentrują się na rozwiązywaniu problemów i/lub podejmowaniu decyzji. Między innymi te koncepcje umożliwiły opracowanie programów nauczania MK, które poważnie różnią się od siebie treściami, preferowanymi metodami i długością kształcenia. Pracując nad koncepcją i programem MK w Polsce, warto uwzględnić ten dorobek, choć nie należy tracić z oczu własnej tradycji filozoficzno-logicznej ${ }^{11}$.

\section{CZYM JEST MYŚLENIE KRYTYCZNE?}

Idea MK współcześnie rozwijała się w trzech perspektywach: filozoficzno-logicznej, psychologicznej i pedagogicznej ${ }^{12}$, w pluralistycznym środowisku północnoamerykańskim, co nie sprzyjało wypracowaniu jednej definicji tego

${ }^{11}$ Mam tutaj na myśli przede wszystkim szkołę lwowsko-warszawską i wybrane prace jej przedstawicieli: Ajdukiewicz, 1953; Ajdukiewicz, 1965; Ajdukiewicz, 1985; Czeżowski, 1958; Czeżowski, 1959; Czeżowski, 1965; Kotarbiński, 1986; Kotarbiński, 1993; Twardowski, 1965. Zobacz omówienia: Woleński, 1985; Woleński, 1989; Woleński, 1994. Zobacz też: Dąbrowski, 2016 (tam dalsza bibliografia).

${ }^{12}$ Wgląd w rozwój MK w ramach tych trzech modeli daje Emily R. Lai w Critical thinking: A literature review research report. Autorka a) dokonuje przeglądu dotychczasowych prób definiowania MK, b) bada, w jaki sposób rozwija się MK, c) podejmuje refleksję nad tym, w jaki sposób nauczyciele mogą pobudzić rozwój umiejętności MK u swoich studentów, i d) analizuje najlepsze praktyki w ocenie umiejętności MK (Lai, 2011). 
zjawiska, wspólnego pojęcia i — w konsekwencji — jednego programu i podręcznika. Oto kilka wybranych definicji MK:

— „strategia poznawcza, polegająca głównie na stałym weryfikowaniu i testowaniu możliwych rozwiązań, służących kontrolowaniu wykonywanej pracy” (Reber, 2000: 389);

— „skłonność i umiejętność angażowania się w aktywność z refleksyjnym sceptycyzmem” (McPeck, 1981: 8);

— „umiejętne i odpowiedzialne myślenie, które ułatwia dobry sąd, ponieważ 1) opiera się na kryteriach, 2) jest samokorygujące (self-correcting) i 3) jest czułe na kontekst" (Lipman, 1988: 39);

— „celowy, samoregulujący się sąd, który prowadzi do interpretacji, analizy, ewaluacji i wnioskowania, jak również do wyjaśnienia jawnych (evidential), konceptualnych, metodologicznych, kryteriologicznych lub kontekstualnych rozważań, na których sąd ten jest oparty” (Facione, 1990: 3);

— „zdyscyplinowane, skierowane na siebie myślenie, które stanowi przykład doskonalenia myślenia stosownego dla określonego trybu lub domeny myśli” (Paul, 1992: 9);

— „myślenie jasne, bezstronne, oparte na rozumie i krytycznej analizie faktów” (Kisielewicz, 2017: 9);

— „ogólny termin na określenie szerokiego zakresu umiejętności poznawczych i dyspozycji intelektualnych wymaganych do efektywnego identyfikowania, analizowania i oceniania argumentów oraz twierdzeń uznawanych za prawdziwe; do odkrycia i przezwyciężenia osobistych uprzedzeń (biases) i przyjętych z góry sądów (preconceptions); do formułowania i prezentowania przekonujących racji dla wsparcia wniosków i do podejmowania rozsądnych, inteligentnych decyzji" (Bassham et al., 2011: 1).

Definicja pierwsza ma charakter słownikowy, zaczerpnięta została ze słownika psychologicznego, choć jej charakter jest prakseologiczny. Kolejne definicje pochodzą z artykułów lub książek a ich autorami są teoretycy MK. Ostatnie określenie nie jest, ściśle rzecz biorąc, definicją, ale najbardziej rudymentarną charakterystyką MK, jaką znajdujemy we wprowadzeniu do podręcznika Critical thinking: A student's introduction. Definicje te - jak większość mi znanych - są niezadowalające przede wszystkim ze względu na zbytnią zwięzłość, ogólnikowość i niejasność lub - to druga skrajność — przesadne rozbudowanie przy równoczesnym braku precyzji. Proponuję zatem własną (roboczą) definicję MK:

Df MK: zdolność intelektualna do analizy i oceny myślenia (i wytworów myślenia) innych oraz własnego, z zachowaniem najwyższych standardów intelektualnych ( $\mathrm{tj}$. jasność, precyzja, poprawność logiczna, rzetelna argumentacja) oraz z zachowaniem czujności na uproszczenia i błędy (poznawcze, semiotyczne i logiczne), połączona z gotowością do kontrargumentowania i formułowania własnych przekonań. 
Od razu niech wolno mi będzie zrobić kilka uwag. Nie jest to definicja równościowa i nie należy oczekiwać, że zakres definiendum i definiensa będą w niej równe. Jest to propozycja definicji projektującej regulującej, a zatem jej cel stanowi nadanie definiowanemu wyrażeniu bardziej ostrego i wyraźnego znaczenia. Uwzględnia ona cztery elementy. Pierwszy dotyczy analizy i oceny. Zgodnie z definicją analiza i ocena dotyczyć mają „myślenia”, a więc przekonań, a także wypowiedzi „innych oraz własnych”, ale mogą dotyczyć również różnorakich wytworów, a nawet faktów w świecie. Chociaż definicja uprzywilejowuje umiejętność analizy i oceny, to jednak nie wyklucza stosowania innych czynności intelektualnych: objaśniania, interpretacji, porównywania czy nawet syntezy. Mogą one wspierać analizę, a wręcz okazać się niezbędne na etapie oceny lub kontrargumentowania. Analizę i ocenę należy przeprowadzić z zachowaniem standardów lub kryteriów (to element drugi definicji) oraz ze świadomością pewnego typu możliwych przeszkód (barier MK), nazwanych tutaj uproszczeniami i błędami (element trzeci). Do tych uproszczeń należą między innymi pochopne uogólnienia, stereotypy i stronniczość, ale też myślenie egocentryczne, życzeniowe i samooszukiwanie ${ }^{13}$. Definicja uwzględnia trzy kategorie błędów: 1) poznawcze, generujące fałszywe przekonania i oceny prawdopodobieństwa, 2) semiotyczne, przede wszystkim semantyczne, dotyczące strony znaczeniowej wyrażeń i syntaktycznej, związane z wadliwą składnią wyrażeń złożonych, oraz 3) logiczne, błędy formalne i materialne w rozumowaniach. Wreszcie definicja wskazuje na „gotowość do kontrargumentowania i formułowania własnych przekonań" (element czwarty), który nie potrzebuje chyba komentarza. Warto natomiast zwrócić uwagę, że wyrażenia „analiza i ocena myślenia [...] innych” oraz "gotowość do kontrargumentowania” łącznie wskazują na to, że MK realizuje się w sytuacjach dialogicznych (choć się do nich nie ogranicza). W dalszej części artykułu nieco dokładniej rozwinę wybrane elementy definicji.

\section{KOMUNIKACYJNY KONTEKST MYŚLENIA KRYTYCZNEGO}

Człowiek rozwija się i funkcjonuje w społeczeństwie. Pierwotnym i najważniejszym kontekstem, w którym rozgrywa się MK, jest zatem kontekst

${ }^{13}$ Do najbardziej rozpowszechnionych barier MK Gregory Bassham, William Irwin, Henry Nardone, James M. Wallace zaliczają: „brak istotnych informacji ogólnych, słabe umiejętności czytania, stronniczość, uprzedzenie, zabobon, egocentryzm (myślenie egocentryczne), socjocentryzm, presja rówieśników, konformizm, prowincjonalizm, ograniczony umysł, zamknięty umysł, nieufność wobec rozumu, myślenie relatywistyczne, stereotypy, przyjmowanie nieuzasadnionych założeń, mechanizm kozła ofiarnego, racjonalizacja, wypieranie, myślenie życzenie, myślenie krótkoterminowe, selektywna percepcja, selektywna pamięć, uleganie przytłaczającym emocjom, oszukiwanie samego siebie, zachowywanie twarzy, strach przed zmianą” (Bassham et al., 2011: 10-11). Przynajmniej niektóre z tych barier — jeśli nie większość — powinna być znana uczniom szkoły średniej. 
wspólnotowy, komunikacyjny i dialogiczny ${ }^{14}$. Pytamy i jesteśmy pytani przez innych, dzielimy się informacjami, bronimy swoich poglądów, przekonujemy do swoich racji, szukamy porozumienia, nawiązujemy współpracę lub z niej rezygnujemy. Żyjemy wśród innych ludzi i jesteśmy skazani na różnego typu sytuacje komunikacyjne. Celem MK jest analiza oraz ocena myślenia i wypowiedzi naszych rozmówców, a także adekwatna reakcja na ich komunikaty. Należy podkreślić, że cel ten obejmuje również nas samych: musimy analizować i oceniać swój sposób myślenia - tylko wtedy można być w pełni krytycznym, gdy jest się krytycznym wobec samego siebie. Nie ma tutaj miejsca na pogłębione analizy tego zagadnienia. Warto jednak odnotować kilka spraw.

Użyte wyżej terminy „dialog” i „dyskusja” są wieloznaczne, czasami stosowane zamiennie. Proponuję przyjąć, że - zgodnie z etymologią - dialog (gr. diálogos: diá - 'przez', logos — 'rozum', 'język', 'mowa'; łac. dialogus) to „rozmowa dwóch podmiotów”. Podmiotem może być osoba, osoby lub instytucje. Dialog mogą dalej dookreślać pewne przymiotniki. A zatem może on być: spokojny, wyważony, motywujący, trudny, żywy i pełen emocji, a także: racjonalny, filozoficzny, społeczny, polityczny, ekumeniczny itd. Sam termin „dialog”, bez przymiotników, ma dosyć ogólne znaczenie i w punkcie wyjścia może być stosowany do opisu spontanicznej rozmowy, luźnej konwersacji lub dyskusji czy polemiki. Choć każda dyskusja może być uznana za dialog, to nie każdy dialog jest dyskusją. Termin „dyskusja” (łac. discussio — 'roztrząsanie') jest bardziej precyzyjny: to wymiana zdań (opinii) na jakiś temat między osobami o odmiennych poglądach, poparta argumentami. Do dialogu jeszcze wrócę, w tym miejscu zatrzymam się na chwilę przy dyskusji. W celu dokładniejszego określenia, czym ona jest, w punkcie wyjścia proponuję odwołać się do rozważań polskich badaczy Tadeusza Czeżowskiego i Tadeusza Kwiatkowskiego.

Ten pierwszy definiuje dyskusję jako

ustną lub pisemną wymianę myśli między dwoma lub więcej uczestnikami, zwykle reprezentującymi przeciwne przekonania lub dążenia, jeżeli jest ona prowadzona w pewnym porządku i zmierza do określonego celu intelektualnego (poznawczego) lub praktycznego (Czeżowski, 1958: 280).

Dyskusja może być zatem — w zależności od celu — teoretyczna lub praktyczna. Kwiatkowski proponuje wprowadzić do tej definicji pewne zmiany terminologiczne, a mianowicie zastąpić określenia „zwykle” i „przeciwne” w wyrażeniu „Zwykle reprezentujących przeciwne przekonania lub dążenia” słowami „często” i „niezgodne”, ponieważ — jak utrzymuje — dyskusje nie muszą być „zwykle”,

${ }^{14}$ Zwrócenie uwagi na ten kontekst jest ważne $\mathrm{z}$ różnych powodów. Przede wszystkim wybija argument z ręki tym, którzy zarzucają obrońcom i propagatorom MK, że jest to typ myślenia egocentrycznego, nastawionego na obronę wyłącznie własnych partykularnych interesów. Autentyczny dialog, dyskusja lub debata rozbrajają silny i ślepy egocentryzm. 
czyli „najczęściej”, polemiczne (mogą dążyć do poznania, mogą coś precyzować, określać lub wyznaczać w duchu jedności i zgody), a tym bardziej stanowiska nie muszą być „przeciwne”, czyli „skrajnie różne”, bo mogą być pod wieloma względami podobne. W rezultacie Kwiatkowski proponuje następującą definicję:

Dyskusja jest to ustna lub pisemna wymiana myśli między dwoma lub więcej uczestnikami, często reprezentującymi niezgodne przekonania lub dążenia, jeżeli jest ona prowadzona w pewnym porządku i zmierza do określonego celu poznawczego lub praktycznego (Kwiatkowski, 2003: 436).

Następnie Kwiatkowski zauważa, że realizacja tak rozumianej dyskusji musi spełniać określone warunki. Te zostały podzielone przez niego na trzy kategorie: 1) warunki moralne (wolność, rzetelne uczestnictwo i działanie wedle reguły: suaviter in modo, fortiter in rei, dosłownie: „możliwie najłagodniej w sposobie i możliwie najmocniej w rzeczy”, czyli uczynić wszystko, żeby obalić pogląd, który jest naszym zdaniem fałszywy, i równocześnie zrobić wszystko, żeby nie uderzyć w osobę, która pogląd ten wyraziła); 2) warunki logiczne i 3) warunki organizacyjno-techniczne. Konieczność warunków moralnych wynika z faktu, że dyskusja jest rodzajem współpracy przynajmniej dwóch osób, a to zakłada relację etyczną między nimi, odpowiednie uprawnienia i obowiązki. Warunki logiczne wiążą się z tym, że dyskusja jest działaniem umysłowo-językowym, które jest przedmiotem praw i reguł szeroko rozumianej logiki. Natomiast warunki organizacyjno-techniczne przesądzają o przebiegu i efektywności dyskusji.

$\mathrm{Z}$ nieco węższym rozumieniem dyskusji mamy do czynienia $\mathrm{w}$ ramach pragma-dialektyki, która operuje pojęciem dyskusji krytycznej. W dyskusji takiej protagonista i antagonista próbują ustalić, czy pewne stanowisko jest możliwe do utrzymania w świetle krytycznych odpowiedzi. Idealny model krytycznej dyskusji zawiera cztery etapy: A. „konfrontacja” (uświadomienie różnicy poglądów), B. etap „otwarcia” (przyjęcie zobowiązań merytorycznych i proceduralnych), C. etap „argumentacji” (przedstawienie i obrona argumentu), D. etap „zakończenia” (ocena skuteczności argumentu i wnioski). W krytycznej dyskusji protagonista i antagonista próbują ustalić, czy pewne stanowisko jest możliwe do utrzymania w świetle krytycznych zarzutów.

W ramach krytycznej dyskusji obowiązują następujące reguły:

1. Strony nie moga sobie na wzajem przeszkadzać w prezentowaniu lub kwestionowaniu stanowisk.

2. Każda ze stron jest zobowiązana do obrony swojego stanowiska, jeśli tylko zostanie o to poproszona.

3. Atakowane powinno być to stanowisko, które rzeczywiście zajmuje przeciwnik.

4. Obrona stanowiska powinna odbywać się za pomocą argumentów, które odnoszą się dokładnie do tego stanowiska. 
5. Protagonista nie może zaprzeczyć przesłance, która została milcząco przez niego przyjęta, a antagonista nie może jej wyolbrzymiać lub przedstawiać fałszywie.

6. Strona nie może fałszywie przedstawiać przesłanki przyjętej wspólnie w punkcie wyjścia ani zaprzeczać przesłankom wywodzącym się z tych, które przyjęte zostały w punkcie wyjścia.

7. Nie może uznać stanowiska za ostatecznie uzasadnione, jeżeli jego obrona nie została przeprowadzona za pomocą prawidłowo dobranego i przeprowadzonego schematu argumentacji.

8. Strony muszą stosować w swojej argumentacji jedynie argumenty logicznie poprawne lub takie, które stają się poprawne po uzupełnieniu brakującej przesłanki.

9. Niepowodzenie w obronie stanowiska musi skutkować wycofaniem strony, która je przedstawia, natomiast w przypadku powodzenia obrony strona przeciwna powinna wycofać wątpliwości.

10. Strony nie mogą używać sformułowań, które nie są wystarczająco jasne lub są mylące przez swą wieloznaczność; sformułowania stron powinny być przeprowadzone ostrożnie i dokładnie (Eemeren \& Grootendorst, 1992: 208-209; Eemeren, Grootendorst, \& Johnson, 2009: 283-284).

Celem dyskusji krytycznej jest rozstrzygnięcie różnicy zdań na drodze argumentacji. Warto jednak pamiętać - o czym wzmiankowałem powyżej — że dyskusja jest tylko szczególnym typem dialogu. Analizę różnych jego typów znajdujemy u Douglasa Waltona. Każdy z nich został przez niego scharakteryzowany za pomocą trzech parametrów: sytuacji początkowej, celu uczestników dialogu oraz celu samego dialogu. Są to:

1. Dialog poznawczo-informacyjny (sytuacja wyjściowa: potrzeba informacji, cel uczestników: zdobycie lub udzielenie informacji, cel dialogu: wymiana informacji).

2. Dialog badawczy (sytuacja wyjściowa: potrzeba dowodu, cel uczestników: znalezienie i weryfikacja dowodu, cel dialogu: udowodnienie lub obalenie hipotezy).

3. Dialog perswazyjny (sytuacja wyjściowa: konflikt opinii, cel uczestników: przekonanie drugiej strony do własnej opinii, cel dialogu: rozwiązanie lub objaśnienie kontrowersji).

4. Dialog negocjacyjny (sytuacja wyjściowa: konflikt interesów, cel uczestników: zdobycie tego, czego się chce, cel dialogu: rozsądna ugoda).

5. Dialog deliberatywny (sytuacja wyjściowa: dylemat lub praktyczny wybór, cel uczestników: koordynacja celów i działań, cel dialogu: wybór najlepszego dostępnego kierunku działania).

6. Dialog erystyczny (sytuacja wyjściowa: personalna konfrontacja, cel uczestników: werbalne uderzenie w przeciwnika, cel dialogu: ujawnienie głębszych podstaw konfliktu) (Walton, 2008: 3 i nn.). 
Lista nie jest oczywiście wyczerpująca. Możliwe są jeszcze inne typy dialogu, na przykład dialog edukacyjno-wychowawczy, zmierzający do kształtowania różnych form myślenia (i osobowości), niesymetryczny, w którym jeden z partnerów jest przewodnikiem osobowym (podaję najbardziej intuicyjną wykładnię, być może dziś mało popularną). Warto też podkreślić, że niektóre przypadki dyskursu argumentacyjnego mogą łączyć w sobie dwa lub więcej z podanych tutaj rodzajów dialogu. Możliwe jest na przykład przeplatanie się modelu negocjacyjnego z deliberatywnym lub poznawczo-informacyjnego z erystycznym.

Dla osoby myślącej krytycznie ważna jest świadomość tego, że nieustannie wchodzimy w dialog i interakcje społeczne, oraz tego, jakie są możliwe rodzaje sytuacji komunikacyjnych lub — jak wyżej — dialogicznych, ponieważ umożliwia to dobranie odpowiednich środków, w tym przede wszystkim strategii argumentacyjnych.

\section{ANALIZA JAKO PODSTAWA MYŚLENIA KRYTYCZNEGO}

Myślenie krytyczne jest myśleniem analitycznym, w którym szeroko wykorzystuje się analizę, polegającą na wyodrębnieniu części z większej całości (analiza ilościowa) i dokładnym ich zbadaniu (analiza jakościowa). Przedmiotem analizy może być pewna czynność i/lub wytwór, w szczególności zaś wypowiedź, jej struktura i treść, a dokładniej mówiąc: terminy i pojęcia (lub układy pojęć), założenia, definicje, twierdzenia i teorie, a zwłaszcza argumenty.

Analiza terminologiczna i pojęciowa zmierza do uchwycenia sensu jakiegoś słowa lub pojęcia, ewentualnie jego związków z innymi pojęciami w danej wypowiedzi naukowej lub pozanaukowej, w debacie społecznej lub codziennym dialogu. Należy zwrócić uwagę przede wszystkim na jasność i ostrość terminologiczną, albowiem niejasne lub źle zdefiniowane słowa wielokrotnie prowadzą do nieporozumień lub błędnych odpowiedzi. Przykładowo, na pytanie: „Czy zwierzęta posługują się językiem?” osoba myśląca krytycznie przypuszczalnie nie odpowie pospiesznie „tak” lub „nie”, zgodnie z pierwszą intuicją, ale będzie domagała się zdefiniowania terminu ,język”. Zapyta rozmówcę: „Co rozumiesz przez termin «język»?”. I w zależności od definicji ostrożnie udzieli odpowiedzi. Podobnie osoba taka zareaguje w przypadku pytania: „Czy zwierzęta mają świadomość?”. Z dużym prawdopodobieństwem poprosi nie tylko o zdefiniowanie terminu „świadomość”, ale z uwagi na to, że zwierzęta są niezwykle różnicowanym gatunkowo królestwem, będzie dopytywać, o które dokładnie gatunki chodzi ${ }^{15}$.

${ }^{15} \mathrm{~W}$ tym kontekście warto też podkreślić ogromną rolę pytania. Osoby, które myślą krytycznie, znają wartość pytania, mają świadomość, że niweluje ono lukę w wiedzy - eliminuje ignorancję. Znają też rodzaje pytań (umożliwiające zdobycie wyczerpujących informacji na temat różnych zdarzeń: „kto?”, „co?”, „gdzie?”, „kiedy?”; otwarte, problemowe: „dlaczego?”; ze 
Każdą wypowiedź należy przeanalizować pod kątem definicji, które gwarantują uzyskanie pełniejszej jasności, wyrazistości i precyzji. To zakłada oczywiście znajomość teorii definicji (przedmiot, struktura i funkcje definicji, a także warunki ich poprawności) oraz podstawowych rodzajów definicji (między innymi aksjomatycznej, klasycznej, sprawozdawczej, projektującej regulującej, projektującej konstrukcyjnej, cząstkowej oraz perswazyjnej). Zakłada to również świadomość możliwych błędów w definiowaniu, do których należą między innymi błędy zakresowe (definicja za wąska, za szeroka, krzyżująca, rozłączna), treściowe (na przykład idem per idem, a dokładniej błędne koło bezpośrednie i błędne koło pośrednie) i pragmatyczne (na przykład ignotum per ignotum).

Następnie analiza powinna prowadzić do rozpoznania założeń, które mógł przyjąć nadawca danej wypowiedzi. Wszyscy robimy pewne założenia, w praktyce naukowo-badawczej ${ }^{16}$, debatach filozoficznych czy społeczno-politycznych i codziennych dyskusjach, choć nie zawsze jesteśmy tego świadomi. Zwykle mają one charakter pewników i niepodważalnych aksjomatów. Tymczasem niektóre z przyjmowanych w założeniach przekonań mogą być de facto tendencyjne, uproszczone lub fałszywe. Takich przekonań nabywamy w wyniku socjalizacji lub błędnej interpretacji idei, teorii i faktów. To natomiast prowadzi konsekwentnie do fałszywych wniosków i kolejnych błędnych twierdzeń. Ktoś może być na przykład przekonany, że jadalna jest tylko biała jodowana sól kuchenna, i upiera się, że himalajska sól różowa nie nadaje się do spożycia, a nawet że nie jest solą, podczas gdy sól himalajska jest jedną z najczystszych soli na świecie. Niektóre cicho przyjmowane założenia mogą z kolei okazać się szkodliwe dla praktyki życia, na przykład przekonanie, że każdy problem ma tylko jedno idealne rozwiązanie albo że istnieje osobowy Bóg jako prawodawca i surowy sędzia.

$\mathrm{Na}$ drodze analizy należy wreszcie ustalić, z jakiego rodzaju argumentem (lub argumentami) mamy do czynienia, i ocenić, czy jest on poprawnie przeprowadzony, czy nie ma w nim ukrytych założeń, czy przesłanki nie są zbyt słabe, a wniosek nie został zbyt pochopnie przyjęty, czy jest to argument przekonywający lub skuteczny. W celu ewaluacji argumentów można zastosować jedną z czterech metod: 1) metodę analizy pod kątem sofizmatów (Howarda Kahane'a), 2) metodę badającą działanie przesłanek w argumencie (Stephena N. Thomasa), 3) metodę oceny przesłanek w pięciostopniowej skali (Marka

względu na zakres problemu: metafizyczne, ogólne, szczegółowe; rozpoczynające się od partykuły „czy”, w tym pytania rozstrzygnięcia; retoryczne i podchwytliwe) i posiadają umiejętność formułowania pytań odpowiednich do sytuacji (na temat pytań zob. Belnap \& Steel, 1976; Brożek, 2007; Wiśniewski, 1995).

${ }^{16}$ Przedstawiciele nauk empirycznych przyjmują na przykład cztery następujące założenia, które nie budzą kontrowersji: 1) istnieje świat realny; 2) świat ten jest w dużej mierze poznawalny; 3) twierdzenia naukowe - przynajmniej niektóre - adekwatnie opisują ten świat; 4) inni mogą zweryfikować wiedzę zdobytą przez nauki empiryczne. Niektórzy proponowali przyjąć też inne, silniejsze założenia, na przykład „nauki empiryczne posługują się wyłącznie rozumowaniami indukcyjnymi”, te jednak okazały się zbyt ograniczające. 
Tokarza) lub 4) metodę oceniania przez obalanie (Krzysztofa A. Wieczorka) (Wieczorek, 2018). Sprawnej ewaluacji argumentów nie da się przeprowadzić bez należytej wiedzy i praktyki argumentacyjnej.

\section{ARGUMENTACJA}

Jednym z podstawowych celów kursów poświęconych MK jest pomoc w zrozumieniu, czym jest argumentacja, czym są (poprawne, dobre i silne) argumenty, jakie istnieją rodzaje argumentów oraz jak je rutynowo stosować. W punkcie wyjścia — jak pokazuje doświadczenie - warto zapoznać studentów z podstawową problematyką języka, jego naturą, strukturą i funkcjami, uświadomić im mnogość różnego rodzaju wypowiedzi, w tym różnicę, jaka istnieje między wypowiedzią argumentacyjną i nieargumentacyjną (uwagi, relacje, sprawozdania, opinie itp.) oraz - w tym kontekście - wprowadzić rozróżnienie na argumenty i dowody - te ostatnie można zaprezentować jako argumenty w najsilniejszym sensie (materialne i dedukcyjne), a następnie wyodrębnić i szeroko omówić podstawowe typy argumentów ${ }^{17}$.

Przez argumentację rozumiem tutaj szukanie i podawanie racji dla uznania lub odrzucenia jakiegoś przekonania, względnie racji do podjęcia pewnego działania lub jego zaniechania. Argumentacja może zawierać jeden lub kilka argumentów. Przez argument rozumiem wyodrębniony z wypowiedzi argumentacyjnej układ zdań, złożony - w idealnej postaci - z przesłanek, słówek-wskaźników i konkluzji, gdzie przesłanka to zdanie będące podstawą procesu argumentowania (może być jedna lub więcej), słówka-wskaźniki to słowa, które pośredniczą między przesłankami (mogą to być słówka-wskaźniki przesłanek: „ponieważ”, „gdyż”, „dlatego że”, lub słówka-wskaźniki wniosków: „a zatem”, „więc”, „dlatego”), wniosek (konkluzja) zaś to zdanie będące rezultatem rozumowania argumentacyjnego. Wiele wypowiedzi argumentacyjnych nie dysponuje jednak wyraźnie wyodrębnionymi argumentami, mają one ukryte przesłanki i domyślne wnioski. Sztuką MK jest zatem odkrywanie również tego, co ukryte i domniemane.

Dobrym pomostem, który łączy ogólną teorię argumentacji z poszczególnymi rodzajami argumentacji, teoretycznej i praktycznej, w tym moralnej, jest teoria rozumowań. Polska szkoła lwowsko-warszawska ma na tym polu duże zasługi $^{18}$. Rozumowanie to działanie na sądach logicznych wedle określonych

${ }^{17}$ Zwięzłe objaśnienie tego, czym jest wypowiedź argumentacyjna i argument oraz jakiego rodzaju argumenty istnieją, znaleźć można w: Szymanek, 2012. Wartościową pozycją pod tym względem jest też praca Marka Tokarza (Tokarz, 2006). Rozważania na temat współczesnych tendencji w teorii argumentacji znaleźć można między innymi w: Eemeren et. al., 2014; Eemeren \& Garssen, 2015.

${ }^{18}$ Mam tutaj na myśli przede wszystkim Jana Łukasiewicza, Tadeusza Czeżowskiego, Tadeusza Kotarbińskiego i Kazimierza Ajdukiewicza. 
reguł logicznych. Zasadniczo rozumowanie dzieli się na zawodne i niezawodne, czyli indukcyjne (względnie redukcyjne, którego szczególnym przypadkiem są rozumowania indukcyjne) i dedukcyjne. Z pewnych względów lepiej jednak przyjąć podział na dedukcyjne, indukcyjne i abdukcyjne. Rozumowanie dedukcyjne polega na wyprowadzaniu logicznych wniosków z przyjętych wcześniej przesłanek: jeśli przesłanki są prawdziwe, to i wniosek w sposób logicznie konieczny będzie prawdziwy. Rozumowanie indukcyjne to rozumowanie uprawdopodobniające, w którym na podstawie pewnej liczby zaobserwowanych przypadków dochodzi się do ogólnego wniosku. Indukcja ma jednak wiele odmian: indukcja enumeracyjna niezupełna i zupełna (ta ostatnia obejmuje określoną i znaną liczbę przypadków i wyjąttkowo może prowadzić do niezawodnego wniosku), indukcja eliminacyjna Francisa Bacona, indukcja eliminacyjna Johna Stuarta Milla oraz rozumowanie per analogiam. Natomiast rozumowanie abdukcyjne jest rozumowaniem „do najlepszego wyjaśnienia”. W rozumowaniu tym stawia się możliwie jak najwięcej hipotez wyjaśniających i wskazuje na najlepsze z możliwych wyjaśnień, korzystając z następujących kryteriów: 1) prostota, 2) spójność (z dotychczasową wiedzą), 3) sprawdzalność (powinien istnieć sposób sprawdzenia hipotezy), 4) szerokozakresowość (im więcej hipoteza wyjaśnia, tym lepiej).

Rozumowania te stanowią podstawowe rusztowanie dla argumentacji naukowej czy filozoficznej. Nauki (w sensie science) dodatkowo odwołują się do przyjętych w ramach poszczególnych dziedzin zasad metodologicznych i procedur badawczych. Podstawę metody naukowej - mówiąc najogólniej — stanowią weryfikacja, czyli potwierdzenie zaproponowanej teorii naukowej, lub falsyfikacja, czyli wykazanie jej fałszywości ${ }^{19}$. Wysokie standardy postępowania naukowego mogą stanowić wzorzec i drogowskaz dla praktyki w życiu codziennym. Filozofowie argumentują inaczej niż naukowcy. Nie ma wśród nich zgody co do uprzywilejowanego typu argumentacji. Przybiera ona różne formy, w zależności od reprezentowanej subdyscypliny filozoficznej, a zwłaszcza kierunku lub nurtu filozoficznego. Wszystkie odmiany argumentacji filozoficznej mieszczą się gdzieś pomiędzy dwoma biegunami: radykalnym scjentyzmem, który domaga się naukowych dowodów, a skrajną hermeneutyką, która ogranicza się do interpretowania, rezygnując z jakichkolwiek odniesień do dowodów naukowych (Cabrera, 2019; Judycki, 2004; Nelson, 2016; Woleński, 1990; Brożek et al., 2020). Jeżeli nauka wskazuje na najwyższe standardy metodologiczne, to z kolei filozofia otwiera na pluralizm metodologiczny i uczy większego intelektualnego wyrafinowania.

Przyjęta powyżej ogólna formuła argumentacji obejmuje również argumentację praktyczną, która dla MK jest bardzo ważna. Zadaniem jej jest

\footnotetext{
${ }^{19}$ Kwestie te są stosunkowo dobrze znane i zostały szeroko omówione w literaturze przedmiotu, zob. Grobler, 2006; Hempel, 2001; Pawłowski, 1959; Janeczek, Walczak, \& Starościc, 2019a; Janeczek, Walczak, \& Starościc, 2019b.
} 
podanie racji za lub przeciw określonemu działaniu. Do tego rodzaju argumentacji zalicza się między innymi argumentację retoryczną, prawniczą czy moralną. Ograniczę się do pierwszej i trzeciej, uznając je za różne, choć nie przeciwstawne $^{20}$.

Przede wszystkim warto podkreślić, że argumentacja retoryczna, choć pozostaje w pewnym związku z teorią, metodologią i logiką, jest podstawowym narzędziem retoryki, czyli praktycznej sztuki przekonywania — skutecznego nakłaniania do podejmowania pewnych działań i/lub unikania innych. Argumentacja retoryczna powinna być skuteczna, czyli ma prowadzić do osiągnięcia zamierzonego przez jednostkę celu, dlatego bardzo ważna jest w niej znajomość sytuacji komunikacyjnej i odbiorcy. Znajomość ta pozwala na odpowiedni dobór stylu wypowiedzi, środków i argumentów ${ }^{21}$, różni ludzie ulegają bowiem różnym środkom perswazji i argumentacji. Do niektórych przemawiają fakty, liczby, dowody i racjonalne argumenty, do innych argumenty perswazyjne (do których należą między innymi dobrze znane zachodniej tradycji: argumentum ad auditorem, argumentum ad baculum, argumentum ad crumenam, argumentum ad bominem, argumentum ad ignorantiam, argumentum ad misericordiam, argumentum ad personam, argumentum ad vanitatem i wiele innych). Szczególnym przypadkiem argumentacji retorycznej i perswazyjnej jest argumentacja emocjonalna, która polega na stosowaniu emocjonalnie zabarwionych - pozytywnie lub negatywnie - terminów i definicji. Do słów o pozytywnym ładunku emocjonalnym niewątpliwie należą: wspaniały, rzetelny, uczciwy, sprawiedliwy, a do słów o negatywnym ładunku: bezwartościowy, szkodliwy, zakłamany itp. W argumentacji perswazyjnej stosować można też różne tropy (metaforę, alegorię, metonimię, synekdochę, peryfrazę, hiperbolę, emfazę) i figury retoryczne (inwersję, elipsę, wyliczanie, powtórzenie, niedomówienie), które wzmacniają efekt przekazu (Korolko, 1990; Ziomek 1990; Jost \& Olmsted, 2004).

Problematyka argumentacji etycznej, choć mniej popularna i bardziej kontrowersyjna, również ma długą historię. Już Arystoteles wskazywał na różne rodzaje argumentów (dydaktyczne, dialektyczne, pejrastyczne i erystyczne) i przekonywał, że obok sylogizmów logicznych istnieją sylogizmy praktyczne.

${ }^{20}$ Niektórzy uważają, że dyskurs etyczny musi nawiązywać do najlepszych naukowych standardów dedukcyjno-indukcyjnych, inni preferują $\mathrm{w}$ nim argumentację retoryczną (perswazyjno-emocjonalną). Tymczasem - jak za chwilę pokażę - uzasadnienie etyczne znajduje się gdzieś pomiędzy ścisłym i rygorystycznym dowodzeniem naukowym i perswazyjną argumentacją w retoryce.

${ }^{21} \mathrm{~W}$ klasycznej retoryce wyróżnia się (za Arystotelesem) trzy rodzaje mów: uzasadniającą (dotyczącą przyszłości), której celem było zachęcenie do czegoś lub odwodzenie od czegoś z uwagi na korzyść lub szkodę, osądzającą (dotyczącą przeszłości), której celem było oskarżenie lub obrona ze względu na działanie sprawiedliwe lub niesprawiedliwe, ale też prawdę i fałsz, oraz oceniającą (dotyczącą zdarzeń teraźniejszych), której celem była pochwała lub nagana (rzeczy, problemów, osób). 
Na taki sylogizm składają się: przesłanka większa - określająca cel, przesłanka mniejsza - wskazująca środki do tego celu, i konkluzja — świadome działanie człowieka. W obszarze życia moralnego Arystoteles nie absolutyzował rozumu. $\mathrm{Na}$ pierwszorzędną jego rolę i racjonalną argumentację stawiali inni (między innymi Sokrates, stoicy, Descartes, a zwłaszcza Immanuel Kant). Tej racjonalnej perspektywie przeciwstawili się później zwolennicy zmysłu moralnego i uczuć moralnych. Poważny wkład w rozumienie natury argumentacji etycznej mają XX-wieczni emotywiści (Alfred Ayer, Charles L. Stevenson, Richard M. Hare), którzy odmawiali sądom etycznym wartości logicznej, widząc w nich przede wszystkim ekspresję uczuć. Wiele jednak wskazuje na to, że argumentacja etyczna powinna uwzględniać zarówno subiektywną intuicję, sferę emocjonalną, jak i racjonalne rozumowania.

Takiego punktu widzenia do pewnego stopnia bronił Hare w Moral thinking: Its levels, method, and point. Jego zdaniem argumentacja moralna w większości przypadków angażuje na pierwszym poziomie myślenie intuicyjne, a następnie racjonalne myślenie krytyczne (Hare, 1981: 25-26). Myślenie intuicyjne podpowiada nam wstępne zasady, za którymi możemy podążać. Są one ogólne i proste. A równocześnie nie są — jak przekonuje Hare — „tylko nasze”, „całkowicie subiektywne”, zostały bowiem zinternalizowane podczas procesu socjalizacji. Ważne jest tutaj założenie, że zasady te można uogólnić na przypadki podobne pod istotnym względem. Zdaniem Hare'a już na tym etapie można rozwiązać wiele problemów moralnych (choć nie wszystkie). Dla pozostałych istotne jest myślenie krytyczne, bezstronne, ale też życzliwe wobec innych i umożliwiające poszukiwanie nowych zasad, bardziej precyzyjnych i przystosowanych do konkretnych wypadków. Na tym etapie nie można już odwoływać się do żadnych intuicji moralnych. Myślenie krytyczne musi uwzględniać wszelkie fakty, okoliczności i wyjątki. Znaczącym elementem dochodzenia do optymalnego rozwiązania jest stawianie się w miejscu innej osoby i przyjmowanie jej preferencji (Hare, 1981: 94-106).

W debatach etycznych można też wykorzystać model argumentacji wypracowany (w perspektywie nowej dialektyki) przez Waltona. Jego zdaniem argumentacja w etyce powinna positkować się rozumowaniem abdukcyjnym i krytycznym dialogiem (Walton, 2003). Celem argumentacji etycznej nie jest bowiem bezwzględne przekonanie drugiej strony, ale poszukiwanie rozwiązania najlepszego (spośród możliwych) dla wszystkich zainteresowanych stron. Szukamy porozumienia, choć wiemy, że na tej płaszczyźnie jest o nie bardzo trudno. To nie zwalnia nas jednak z obowiązku argumentowania i ostatecznie szukania jakiegoś kompromisu ${ }^{22}$.

$\mathrm{Na}$ koniec warto może nadmienić, że współczesne badania nad argumentacją mają charakter wybitnie interdyscyplinarny, wychodzą daleko poza logikę

${ }^{22} \mathrm{Na}$ temat argumentacji etycznej w kontekście MK zob. Curtler, 2004. 
formalną, obejmując logikę nieformalną, retorykę, dialektykę, sztukę komunikacji (w tym prowadzenia dyskusji) czy teorię języka, i mogą już poszczycić się imponującymi osiągnięciami ${ }^{23}$. Ciekawe i ważne dokonania ma również Polska Szkoła Argumentacji ${ }^{24}$. Nauczanie MK powinno systematycznie asymilować najnowsze wyniki i w ten sposób usprawniać sztukę argumentacji, zwłaszcza w życiu codziennym i społeczno-politycznym.

\section{ZAKOŃCZENIE}

Myślenie krytyczne jest istotnym i pożądanym typem myślenia, zwłaszcza dla dojrzałego funkcjonowania w świecie demokratycznym. Od wielu dekad naucza się go w Stanach Zjednoczonych Ameryki, Kandzie, Australii czy Wielkiej Brytanii. W Polsce idea MK jest stosunkowo mało znana i chyba niedoceniana, choć potrzeba kształtowania samodzielnego, dojrzałego i rzetelnego myślenia jest u nas duża, a być może nawet większa niż gdziekolwiek indziej. W artykule zaproponowałem odchudzony wariant idei MK, skoncentrowany na analizie, ocenie i argumentacji. Za taką ograniczoną wersją przemawia moim zdaniem kilka argumentów, spośród których jeden jest szczególnie ważny. Otóż niektóre idee i programy nauczania MK są nieustannie wzbogacane o kolejne elementy. Powstają też nowe ambitne idee, wprowadzające szeroki zakres treści i kompetencji. Czasami obejmują one wiele kwestii teoriopoznawczych, logiczno-metodologicznych, semiotycznych, a zwłaszcza historyczno-filozoficznych. W ten sposób program MK upodabnia się do programu jakiejś - tylko trochę okrojonej - wersji filozofii, która uczy różnych form myślenia filozoficznego $^{25}$. Wówczas jednak wyrażenie „myślenie krytyczne” staje się wyrażeniem definiującym filozofię (jak to jest na przykład u Lorda Quintona). Tymczasem chodzi o to, aby przydawki modyfikujące rzeczownik „myślenie” w nazwach „myślenie krytyczne” i „myślenie filozoficzne” wyznaczały jednak inne zakresy,

${ }^{23}$ Szczególne miejsce zajmuje tutaj logika nieformalna, która pojawiła się mniej więcej pod koniec lat 70. XX wieku jako odpowiedź na przesadny formalizm i nieustającą potrzebę przystępnego kształcenia logicznego myślenia i argumentowania, ważnego również dla życia codziennego czy dla debat społeczno-politycznych (Johnson \& Blair, 1994; Hitchcock, 2017; Walton, 2008). Dynamiczny rozwój przeżywa również pragma-dialektyka (Budzyńska \& Koszowy, 2015).

${ }^{24} \mathrm{Na}$ temat misji Polskiej Szkoły Argumentacji informacje znaleźć można na stronie internetowej: https://argdiap.pl/ (25.02.2021). Na temat postulatów edukacyjnych Szkoły zob. Fedorowicz, 2018: 131-137.

${ }^{25}$ Niektórzy uważają nawet, że nie ma specjalnej potrzeby programu i kursów MK, ponieważ wszystko to, czego ono uczy, zawarte jest już na przykład w ramach filozofii wykładanej na większości uniwersytetów w Polsce. Trudno jednak wymagać od tych, którzy chcą ćwiczyć i praktykować myślenie krytyczne, aby kończyli studia filozoficzne. Poza tym choć filozofia niewątpliwie uczy refleksyjnego myślenia, to jednak zakłada też olbrzymi pluralizm założeń, metod, doktryn i szkół, dopuszcza twórczą spekulację i nie zawsze sprzyja jasności i precyzji. 
cele i zadania. Zaprezentowane tutaj ujęcie MK nie wymaga i nie zakłada dobrej znajomości filozofii, a jednak daje wiele ważnych wskazówek, jak skutecznie wzmocnić postawę krytyczną.

\section{BIBLIOGRAFIA}

Ajdukiewicz, K. (1953). Zarys logiki. Ksiażka pomocnicza dla nauczycieli. Warszawa: PZWS.

Ajdukiewicz, K. (1965). Logika pragmatyczna. Warszawa: Państwowe Wydawnictwo Naukowe. Ajdukiewicz, K. (1985). Jezzyk i poznanie (t. 1-2). Warszawa: Państwowe Wydawnictwo Naukowe.

Bacon, F. (1955). Novum Organum. (Przeł. J. Wikarjak). Warszawa: Państwowe Wydawnictwo Naukowe.

Bailin, S. (2002). Critical thinking and science education. Science \& Education, 11(4), 361-375.

Bassham, G., Irwin, W., Nardone, H., \& Wallace, J.M. (Red.). (2011). Critical thinking. A student's introduction. New York: Mc Graw-Hill.

Belnap, N. \& Steel, T. (1976). The logic of questions and answers. New Haven: Yale University Press.

Black, M. (1946). Critical thinking: An introduction to logic and scientific method. New York: Prentice-Hall.

Blair, A.J. (2006). Informal logic's influence on philosophy instruction. Informal Logic, 26(3), 259-286.

Bloom, B.S. (1956). Taxonomy of educational objectives: The classification of educational goals. New York: Longsmans, Green.

Boardman, F. \& Cavender, N.M. (2017). Logic and contemporary rbetoric the use of reason in everyday life. Boston: Cengage Learning.

Browne, M.N. \& Keeley S.M. (2017). Asking the right questions: A guide to critical thinking. Upper Saddle River: Prentice Hall.

Brożek, A. (2007). Pytania i odpowiedzi. Tło filozoficzne, teoria, zastosowania praktyczne. Warszawa: Wydawnictwo Semper.

Brożek, A. (2010). Ne sutor contra crepidam. Kazimierz Twardowski o filozofii i nauce. Zagadnienia Filozoficzne $w$ Nauce, 46, 3-31.

Brożek, A., Będkowski, M., Chybińska, A., Ivanyk, S., \& Traczykowski, D. (Red.). (2020). Antyirracjonalizm. Metody filozoficzne w Szkole Lwowsko-Warszawskiej. Warszawa: Wydawnictwo Semper.

Budzyńska, K. \& Koszowy, M. (2015). Strategie retoryczne, techniki komunikacyjno-poznawcze, btędy $i$ sofizmaty. Warszawa: Wydawnictwo IFiS PAN.

Cabrera, J. (2019). Introduction to a negative approach to argumentation: towards a new etbic for philosophical debate. Cambridge: Scholars Publishing.

Chaffee, J. (2010). Thinking critically (10th ed.). Boston: Wadsworth Cengage Learning.

Chalmers, A. (1993). Czym jest to, co zwiemy nauką?. (Tłum. A. Chmielewski). Wrocław: Siedmioróg.

Chudy, W. (1984). Rola refleksji w epistemicznej i ontycznej strukturze osoby ludzkiej. Studia Philosopbiae Christianae, 20(1), 7-29.

Curtler, H.M. (2004). Ethical argument: Critical thinking in ethics. Oxford: Oxford University Press.

Czeżowski, T. (1958). Odczyty filozoficzne. Toruń: Towarzystwo Naukowe w Toruniu. 
Czeżowski, T. (1959). Główne zasady nauk filozoficznych. Wrocław: Zakład Narodowy im. Ossolińskich.

Czeżowski, T. (1965). Filozofia na rozdrożu. Analizy metodologiczne. Warszawa: Państwowe Wydawnictwo Naukowe.

Dąbrowski, A. (2016). Czy logika pragmatyczna jest dobrą alternatywą edukacyjną dla krytycznego myślenia?. Nauka, 2, 143-162.

Descartes, R. (2002). Rozprawa o metodzie. (Przeł. T. Żeleński-Boy). Kęty: Antyk.

Dewey, J. (1988). Jak myślimy?. (Przeł. Z. Bastgenówna). Warszawa: Państwowe Wydawnictwo Naukowe.

Edukacja obywatelska w Europie. Agencja Wykonawcza ds. Edukacji, Kultury i Sektora Audiowizualnego (EACEA). Dostęp: http://eurydice.org.pl/wpcontent/uploads/2014/11/citizen_PL.pdf (28.08.2020).

Eemeren, F.H. van \& Grootendorst, R. (1992). Argumentation, communication, and fallacies: A pragma-dialectical perspective. New York: Routledge.

Eemeren, F.H. van, Grootendorst, R., \& Johnson, R.H., (2009). Fundamentals of argumentation theory: A bandbook of historical backgrounds and contemporary developments. New York, London: Routledge.

Eemeren, F.H. van, Garssen, B., Krabbe, E.C.W., Henkemans, A.F.S., Verheij, B., \& Wagemans, J.H.M. (2014). Handbook of argumentation theory. Dordrecht: Springer.

Eemeren, F.H. van \& Garssen, B. (Red.). (2015). Reflections on theoretical issues in argumentation. Dordrecht: Springer.

Ennis, R.H. (1962). A concept of critical thinking. Harvard Educational Review, 32(1), 81-111.

Ennis, R.H. (1987). A taxonomy of critical thinking dispositions and abilities (s. 9-96). W: J.B. Baron \& R.J. Sternberg. (Red.). Teaching thinking skills: Theory and practice. New York: Freeman and Company.

Ennis, R.H. (1989). Critical thinking and subject specificity: clarification and needed research. Educational Researcher, 18(3), 4-10.

Ennis, R.H. (1991). Critical thinking: A streamlined conception. Teaching Pbilosophy, 14(1), $5-20$.

Ennis, R.H. (1996). Critical thinking. Upper Saddle River: Prentice-Hall.

Ennis, R.H. (2011a). Critical thinking: Reflection and perspective part I. Inquiry: Critical Thinking Across the Disciplines, 26(1), 4-18.

Ennis, R.H. (2011b). Critical thinking: Reflection and perspective part II. Inquiry: Critical Thinking Across the Disciplines, 26(2), 5-19.

Facione, P.A. (1990). Critical thinking: A statement of expert consensus for purposes of educational assessment and instruction. Millbrae: The California Academic Press.

Fedorowicz, M. (2018). Argumentacja w edukacji. Postulaty badań edukacyjnych w Polskiej Szkole Argumentacji. Studia Semiotyczne, 32(3), 131-137.

Giuseff, F.G. (2015). Ancient thinking and modern challenges: Socratic education in the 21st century (s. 1-20). W: S. Wisdom \& L. Leavitt. (Red.). The bandbook of research on advancing critical thinking in higher education. Hershey: IGI Global.

Glaser, E. (1941). An experiment in the development of critical thinking. New York: Bureau of Publications, Teachers College, Columbia University.

Górniak-Kocikowska, K. (2014). Krytyczne myślenie a krytyczne słuchanie. Przyczynek do dydaktyki filozofii. Analiza i Egzystencja, 25, 19-30.

Groarke, L. \& Tindale, C. (2013). Good reasoning matters!. Toronto: Oxford University Press.

Grobler, A. (2006). Metodologia nauk. Kraków: Aureus. 
Halpern, D.F. (1998). Teaching critical thinking for transfer a cross domains: Dispositions, skills, structure, training, and metacognitive monitoring. American Psychologist, 53(4), 449-455.

Hare, R.M. (1981). Moral thinking: Its levels, method, and point. New York: The Clarendon Press / Oxford University Press.

Hempel, C. (2001). Filozofia nauk przyrodniczych. Warszawa: Aletheia.

Hitchcock, D. (2017). On reasoning and argument essays in informal logic and on critical thinking. Dordrecht: Springer.

Janeczek, S., Walczak, M., \& Starościc A. (Red.). (2019a). Metodologia nauk (cz. I: Czym jest nauka?). Lublin: Katolicki Uniwersytet Lubelski.

Janeczek, S., M. Walczak i A. Starościc (Red.). (2019b). Metodologia nauk (cz. II: Typy nauk). Lublin: Katolicki Uniwersytet Lubelski.

Johnson, R.H. \& Blair, J.A. (1994). Logical self-defense. New York: McGraw-Hill.

Jost, W. \& Olmsted, W. (Red.). (2004). A companion to rbetoric and rhetorical criticism. Malden: Blackwell Publishing Ltd.

Judycki, S. (2004). Czy istnieją rozstrzygające argumenty filozoficzne?. Diametros, 2, 39-56.

Kahane, H. (1971). Logic and contemporary rhetoric. The use of reasoning in everyday life. Belmont: Wadsworth.

Kanhneman, D. (2011). Thinking fast and slow. New Yok: Farrar, Straus and Giroux.

Kisielewicz, A. (2017). Logika i argumentacja. Praktyczny kurs krytycznego myslenia. Warszawa: Wydawnictwo Naukowe PWN.

Korolko, M. (1990). Sztuka retoryki. Przewodnik encyklopedyczny. Warszawa: Wiedza Powszechna.

Kotarbiński, T. (1986). Elementy teorii poznania, logiki formalnej i metodologii nauk. Warszawa: Państwowe Wydawnictwo Naukowe.

Kotarbiński, T. (1993). Dzieła wszystkie (t. 2: Ontologia, teoria poznania i metodologia nauk). Wrocław-Warszawa-Kraków: Wydawnictwo Polskiej Akademii Nauk / Zakład Narodowy im. Ossolińskich.

Kwiatkowski, T. (2003). Wykłady i szkice z logiki ogólnej. Lublin: Wydawnictwo UMCS.

Lai, E.R. (2011). Critical thinking: A literature review research report. London: Parsons Publishing.

Lipman, M. (1988). Critical thinking. What can it be?. Educational Leadership, 46(1), 38-43.

Long, J.D. (2015). Critical thinking, Socratic seminars, and the college classroom (s. 48-67). W: Sh. Wisdom \& L. Leavitt (Red.). Handbook of research on advancing critical thinking in bigher education. Lindenwood University in Saint Charles USA: Information Science Reference.

McPeck, J.E. (1981). Critical thinking and education. New York: St. Martin's Press.

McPeck, J.E. (1990). Critical thinking and subject specificity: A reply to Ennis. Educational Researcher, 19(4), 10-12.

Nelson, L. (2016). A theory of philosopbical fallacies. New York: Springer.

Paul, W.R. (1992). Critical thinking. What, why, and how?. New Directions for Community Colleges, 77(9), 3-24.

Paul, W.R. (1993). Critical thinking. What every person needs to survive in a rapidly changing world. Rohnert Park: Center for Critical Thinking and Moral Critique / Sonoma State University.

Paul, W.R. \& Elder, L. (2002). Critical thinking. Tools for taking charge of your professional and personal life. Englewood Cliffs: Financial Times Prentice Hall.

Paul, W.R. \& Elder, L. (2004). The thinker's guide to the nature and functions of critical \& creative thinking. Dillon Beach: Foundation for Critical Thinking. 
Paul, W.R. \& Elder, L. (2007). Critical thinking. The art of Socratic questioning. Journal of Developmental Education, 31(1), 32-37.

Pawłowski, T. (1959). Z metodologii nauk przyrodniczych. Warszawa: Państwowe Wydawnictwo Naukowe.

Reber, A.S. (2000). Stownik psychologii. (B. Janasiewicz-Kruszyńska, J. Kowalczewska, J. Kubicka-Daab, P. Matyja, G. Mizera, J. Rączaszek, J. Suchecki, M. Zagrodzki, J. Zychowicz, P. Żylicz). Warszawa: Scholar.

Sadegh-Zadeh, K. (2012). Handbook of analytic philosopby of medicine. Dordrecht: Springer.

Scheffler, I. (1960). The language of education. Springfield: Charles C. Thomas.

Scheffler, I. (1966). Philosophy and education: Modern readings. Boston: Allyn and Bacon.

Scheffler, I. (1973). Reason and teaching. Indianapolis: Bobbs-Merrill.

Scheffler, I. (1985). Of buman potential: An essay in the philosophy of education. Boston: Routledge \& Kegan Paul.

Scheffler, I. (1997). Symbolic worlds: Art, science, language, ritual. Cambridge: Cambridge University Press.

Siegel, H. (1988). Educating reason: Rationality, critical thinking and education. New York: Routledge.

Siegel, H. (1989). Why be rational? On thinking critically about critical thinking (s. 392-401). W: R. Page (Red.). Philosophy of education proceedings of the forty-fifth Annual Meeting of the Philosophy of Education Society. Normal: Philosophy of Education Society.

Siegel, H. (1993). Not by skill alone. The centrality of character to critical thinking. Informal Logic, 15(3), 163-177.

Siegel, H. (1997). Rationality redeemed? Further dialogues on an educational ideal. New York: Routledge.

Siegel, H. (1999). What (good) are thinking dispositions?. Educational Theory, 49(2), 207-221.

Siegel, H. (2003). Cultivating Reason (s. 305-317). W: R. Curren (Red.). A companion to the philosopby of education. Oxford: Blackwell.

Siegel, H. (2019). Myślenie krytyczne i indoktrynacja. (Przeł. P. Kostyło \& K. Nowak). Bydgoszcz: Wydawnictwo UKW.

Sternberg, R.J. (1986). Critical thinking. Its nature, measurement and improvement. Singapore: National Institute of Education.

Szymanek, K. (2012). Sztuka argumentacji. Stownik terminologiczny. Warszawa: Wydawnictwo Naukowe PWN.

Thomas, S.N. (1986). Practical reasoning in natural language. Englewood Cliffs: Prentice-Hall.

Tokarz, M. (2006). Argumentacja. Perswazja. Manipulacja. Gdańsk: Gdańskie Wydawnictwo Psychologiczne.

Twardowski, K. (1965). Wybrane pisma filozoficzne. Warszawa: Państwowe Wydawnictwo Naukowe.

Van Gelder, T. (2005). Teaching critical thinking. Some lessons from cognitive science. College Teaching, 53(1), 41-48.

Walton, D.N. (2003). Ethical argumentation. Lanham: Lexington Books.

Walton, D. (2008). Informal logic. A pragmatic approach. Cambridge: Cambridge University Press.

Wasilewska-Kamińska, E. (2016). Myślenie krytyczne jako cel ksztatcenia. Warszawa: WUW.

Weinstein, M. (1991). Critical thinking and education for democracy. Educational Pbilosophy and Theory, 23(2), 9-29.

Wieczorek, K.A. (2018). Ocena argumentów w kontekście nauczania krytycznego myślenia. Studia Semiotyczne, 32(1), 113-138. 
Willingham, D.T. (2007). Critical thinking. Why is it so hard to teach?, American Educator, 31, s. 8-19.

Wisdom, S. \& Leavitt, L. (Red.). (2015). The handbook of research on advancing critical thinking in bigher education. Hershey: IGI Global.

Wiśniewski, A. (1995). The posing of questions: Logical foundations of erotetic inferences. Dordrecht: Kluwer Academic Publishers.

Woleński, J. (1985). Filozoficzna szkoła lwowsko-warszawska. Warszawa: Państwowe Wydawnictwo Naukowe.

Woleński, J. (1989). Logic and philosophy in the Lvov-Warsaw School. Dordrecht: Kluwer Academic Publishers.

Woleński, J. (1990). Argumentacje filozoficzne. Edukacja Filozoficzna, 10, 43-60.

Woleński, J. (Red.). (1994). Philosophical logic in Poland. London-Dordrecht: Kluwer Academic Publishers.

Ziomek, J. (1990). Retoryka opisowa. Wrocław-Warszawa-Kraków: Zakład Narodowy im. Ossolińskich. 
